\title{
Studies on Human Platelet Granules and Membranes*
}

\author{
Aaron J. Marcus, $\dagger$ Dorothea Zucker-Franklin, Lenore B. Safier, and \\ HARRIS L. UlLmaN \\ (From the Hematology Section, New York Veterans Administration Hospital, the Department \\ of Medicine, Cornell University Medical College, and the Department of Medicine \\ and Rheumatic Diseases Study Group, New York University School of \\ Medicine, New York, N.Y.)
}

Some of the numerous biochemical substances that have been identified in blood platelets are associated with known platelet functions (1), but the role of many others is not clear (2). Since most previous investigations had been carried out on whole platelets, we initiated a study of enzymes and coagulation properties of isolated subcellular platelet components.

Preliminary investigations, employing differential centrifugation, provided useful information, but were not entirely satisfactory due to unavoidable mixing of membrane and granule fractions (3). However, by means of isopycnic gradient ultracentrifugation, platelet homogenates were satisfactorily fractionated and studied (4). This report describes the preparation of platelet homogenates, their separation by ultracentrifugation in a continuous sucrose gradient, identification of the fractions by electron microscopy, and some biochemical and physiological properties of the resulting components.

\section{Methods}

The starting material was $425 \mathrm{ml}$ of whole blood obtained from a fasting donor with a normal platelet count. Collection was carried out in plastic bags with either acid-citrate-dextrose solution or EDTA as anticoagulant. ${ }^{1}$ The bag was centrifuged at $400 \times g$ for 15 minutes $\left(4^{\circ} \mathrm{C}\right)$ and the platelet-rich plasma transferred to $45-$ or $50-\mathrm{ml}$ conical polypropylene tubes. ${ }^{2}$ The platelet-rich plasma was centrifuged for 30 minutes $\left(4^{\circ}\right)$ at $2,000 \times g$. The

* Submitted for publication July 12, 1965 ; accepted September 22, 1965.

Supported by grants from the National Institutes of Health (HE-09070-02 and AM-01431), the Veterans Administration, and the New York Heart Association.

$\dagger$ Address requests for reprints to Dr. Aaron J. Marcus, N. Y. V.A. Hospital, 408 First Ave., New York, N. Y. 10010.

1 Fenwal Laboratories, Morton Grove, Ill.

2 Nalgene, Nalge Co., Rochester, N. Y. platelet buttons were shaken in buffer (5) and centrifuged at $2,000 \times g$ for 20 minutes, and this was repeated once. Less than 2 hours elapsed between collection and platelet homogenization.

Preparation of platelet homogenate. One $\mathrm{ml}$ of packed platelets was finally obtained in each of two tubes and homogenized separately. One $\mathrm{ml}$ of $0.44 \mathrm{M}$ sucrose (0.001 M EDTA) was added, the tubes were shaken, and the mixture was transferred to a clear-walled tube ${ }^{3}$ submerged in ice. Homogenization was carried out with a Teflon pestle, ${ }^{4}$ which was rotated by motor ${ }^{5}$ at 1,700 rpm for 5 minutes. Excursions of the homogenizing tube were limited to ensure constant contact with the platelet mass.

With this apparatus, the Teflon pestle did not fit inside the tube at $20^{\circ} \mathrm{C}$. However, it contracted after a few minutes at $4^{\circ}$ and re-expanded slightly during homogenization, thereby enhancing it. The tube and plunger were washed twice with $2 \mathrm{ml} 0.44 \mathrm{M}$ sucrose ( $0.001 \mathrm{M}$ EDTA), and the procedure was repeated with the second aliquot of platelets. The combined homogenate and washes (about $10 \mathrm{ml}$ ) were pooled in a $15-\mathrm{ml}$ conical glass tube and centrifuged for 30 minutes at $2,000 \times g$ in a swing-out head. The resulting sediment (about $0.3 \mathrm{ml}$ ) consisted of intact platelets, granules, and cellular debris. The supernatant material, when examined by electron microscopy, consisted of granules and membranes but no "intact" platelets. A sample of supernatant (hereafter referred to as the homogenate) was removed for protein determination and the remainder layered on sucrose gradients in approximately $1.2-\mathrm{ml}$ amounts. In a series of pilot studies, other types of homogenizing apparatus were unsatisfactory when the results were studied in the electron microscope.

Preparation of continuous sucrose gradient. The sucrose gradient was prepared at $4^{\circ}$ immediately before use in a commercially available apparatus. ${ }^{6}$ A continuous 30 to $60 \%$ gradient ( $0.001 \mathrm{M}$ EDTA) was most suitable for separation of platelet particles. Linearity of the gradient

${ }^{3}$ No. K88600, size D, Kontes Glass Co., Vineland, N. J.

4 No. 12-152-A ("no clearance"), Kontes Glass Co., Vineland, N. J.

5 Type NS3S, Krebs Electric \& Mfg. Co., New York, N. Y.

6 No. 2-5051, with polystaltic pump, Buchler Instruments, Fort Lee, N. J. 
was periodically checked by addition of methyl orange to the $30 \%$ sucrose (6). Between preparations of gradient tubes, the mixing chamber of the apparatus was washed with $60 \%$ sucrose.

Centrifugation and collection of fractions. Ultracentrifugation was carried out in the Spinco model L-2 HV for 2 hours at $3^{\circ} \mathrm{C}$. The SW-39 L head was used at a speed of $39,400 \mathrm{rpm}(130,576 \times g$ at the center of the tube). After centrifugation, the tubes were capped with a rubber stopper connected by glass and rubber tubing to an air-filled syringe. The bottom of each tube was pierced with a 26-gauge needle, and fractions were collected manually.

The fractions were washed in $0.25 \mathrm{M}$ sucrose with or without EDTA. This was carried out in an SW-39 L head. The membranes were sedimented at $39,400 \mathrm{rpm}$ for 1 hour, and the granules were recovered at $20,000 \mathrm{rpm}$ $(43,824 \times g$ at the bottom of the tube) for 20 minutes. Washed pellets were gently resuspended in appropriate buffer. Occasionally mild homogenization was required.

When necessary, the subcellular particles were stored at $-85^{\circ} \mathrm{C}$.

Electron microscopy. Fractions prepared for electron microscopy were not washed or stored. After collection from the gradient tube, they were immediately fixed by addition of an equal volume of $2 \%$ osmic acid (7). Subsequently the formed elements were sedimented by low speed centrifugation. Alternatively centrifugation was carried out first, followed by fixation of the pellet with $1 \%$ osmic acid. Fixation time ranged from 5 to $30 \mathrm{~min}-$ utes. Dehydration with increasing concentrations of alcohol and propylene oxide was followed by embedding in Epon 812, as previously described (3). It was necessary to centrifuge the specimens at each step of the procedure, since cellular organelles do not sediment in the embedding media by gravity alone. Thin sections, prepared with an LKB Ultrotome, were placed on formvar-coated 7 copper grids, stained with lead hydroxide (8), and viewed with a Siemens Elmiskop 1 electron microscope at magnifications ranging from 6,000 to 30,000 .

Protein analysis. The technique of Lowry, Rosebrough, Farr, and Randall (9), as modified by Miller (10), was employed, with human serum albumin as a standard.8

Cytochrome c oxidase. Stock solution of cytochrome c (horse heart, type III) ${ }^{9}$ was prepared by dissolving it in Tris buffer $(0.02 \mathrm{M}, \mathrm{pH} 7.4,0.001 \mathrm{M}$ EDTA) at a concentration of $6.1 \mathrm{mg}$ per $\mathrm{ml}\left(5 \times 10^{-4} \mathrm{M}\right.$ cytochrome c) $(6,11)$. Reduction of cytochrome c was carried out with sodium borohydride (12). A few crystals were added to $10 \mathrm{ml}$ of cytochrome $\mathrm{c}$ solution and allowed to stand for 10 minutes at room temperature. Per cent reduction was determined by utilizing the equation reported by Smith (13). If the ratio OD 550/OD 565 was

${ }^{7}$ Formvar $=$ polyvinyl-formaldehyde in ethylene dichloride.

${ }^{8}$ Kindly provided by Dr. Alan Johnson, New York University School of Medicine.

9 Sigma Chemical Company, St. Louis, Mo. less than 6 , the proportion of reduced cytochrome $\mathrm{c}$ was too low for use, and additional sodium borohydride was required. After reduction, the cytochrome $\mathrm{c}$ was dialyzed at $5^{\circ} \mathrm{C}$ for 15 hours against two changes of buffer $(2,000 \mathrm{ml}$ each). Reduced cytochrome $\mathrm{c}$ was stored in glass-stoppered tubes under nitrogen (14) at $-20^{\circ}$.

For assay, test samples were diluted $1: 4$ in $0.02 \mathrm{M}$ Tris buffer ( $\mathrm{pH} 7.4,0.001$ M EDTA). Measurements were carried out at room temperature in Tris buffer (6, 15 ) in a total volume of $3 \mathrm{ml}$. Thus, the assay tube contained $0.23 \mathrm{ml}$ reduced cytochrome c, $2.57 \mathrm{ml}$ buffer, and $0.2 \mathrm{ml}$ of diluted sample. Readings were taken at $550 \mathrm{~m} \mu$ in the Beckman DU spectrophotometer every 30 seconds for 10 minutes. Finally, the cytochrome c was completely oxidized by addition of one drop of saturated $\mathrm{K}_{3} \mathrm{Fe}(\mathrm{CN})_{B}(13)$ and a final reading taken. Before each set of assays, a blank run was carried out with buffer and reduced cytochrome $\mathrm{c}$ alone to test for autoxidation.

Calculations were based on first-order reaction kinetics of the oxidation of cytochrome $c(13,16)$. The optical density value of the completely oxidized sample $(\mathrm{OD} \infty)$ was subtracted from the optical density values obtained during the course of the reaction. When these were plotted on the logarithmic scale of semilogarithmic paper against time, a straight line, the slope of which was proportional to enzyme activity, was obtained. Activity was expressed as follows: $\left[\log (\mathrm{OD}-\mathrm{OD} \infty) \mathrm{t}_{1}-\log (\mathrm{OD}-\right.$ $\left.\mathrm{OD} \infty) \mathrm{t}_{2}\right] /\left[\mathrm{t}_{2}-\mathrm{t}_{1}\right]$, where $\mathrm{t}$ was measured in seconds.

Acid phosphatase. The substrate was $p$-nitrophenylphosphate, prepared as directed by the supplier. ${ }^{10}$ Enzyme activity was determined as for serum acid phosphatase. The calibration curve was modified in the following manner: optical density values were plotted against micromoles $p$-nitrophenol per $6.2 \mathrm{ml}$, the final volume of each assay tube. In most instances the total incubation time was 15 minutes. The unit employed was defined as the phosphatase activity that could liberate 1 $\mu$ mole of $p$-nitrophenol per hour under the specified conditions.

Beta-glucuronidase. This was based on the method of Fishman, Springer, and Brunetti (17). The assay tube contained $0.8 \mathrm{ml}$ acetate buffer $(0.1 \mathrm{M}, \mathrm{pH} 4.5), 0.1 \mathrm{ml}$ substrate (phenolphthalein mono- $\beta$-glucuronidate, ${ }^{9} \quad 0.01$ $\mathrm{M}, \mathrm{pH} 7$ ), and distilled water plus sample to bring the final volume to $1 \mathrm{ml}$. When Triton $\mathrm{X}-100$ was used, the final concentration in the incubation tube was $0.15 \%$ (vol/vol). Before addition of test sample, the tube was heated to $37^{\circ}$ for 5 minutes. After a 3-hour incubation period, $5 \mathrm{ml}$ of glycine buffer $(0.2 \mathrm{M}, \mathrm{pH} 10.4$ in $0.2 \mathrm{M}$ $\mathrm{NaCl})^{9}$ was added. Finally the tubes were centrifuged for 10 minutes at $1,000 \times g$; the supernatant was aspirated and the color read against a reagent blank at 550 $\mathrm{m} \mu$. Optical density readings were converted to micrograms phenolphthalein released by reference to a standard phenolphthalein curve. The unit was that activity which liberated $1 \mu \mathrm{g}$ of phenolphthalein per hour.

Cathepsin. The method of Gianetto and De Duve (18, 19) was used. Measurements were made only for total

10 Sigma Technical Bulletin No. 104. 


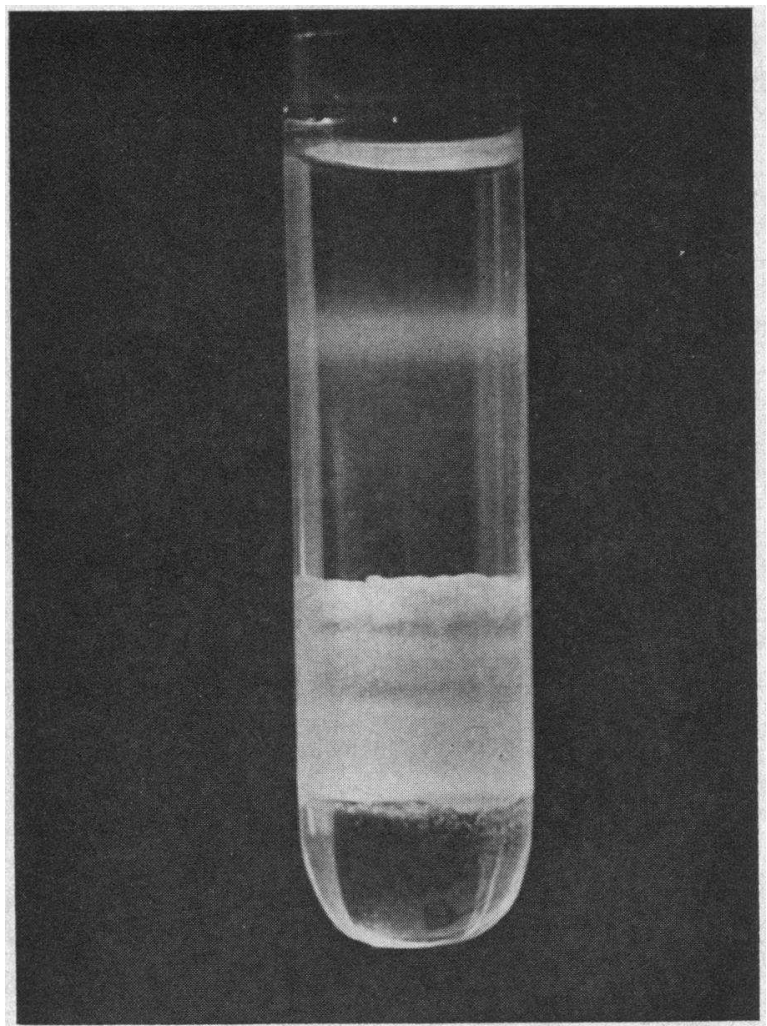

Fig. 1. Photograph of 5-ML centrifuge tube showING THE TWO MAIN PARTICULATE BANDS RESULTING FROM ULTRACENTRIFUGATION OF 1.2 ML OF PLATELET HOMOGENATE (8 MG PROTEIN).

cathepsin activity. The substrate was denatured bovine hemoglobin, prepared by bringing a $2.1 \%$ solution (twice crystallized) $^{9}$ to a $\mathrm{pH}$ of 3.6 with lactate buffer. The hemoglobin was initially dissolved in $0.15 \mathrm{M}$ lactate buffer, $\mathrm{pH} 3.6$, and the $\mathrm{pH}$ readjusted to 3.6 with lactic acid. The final concentration of lactate plus lactic acid was approximately 0.18 mole per $L$. The solution was then incubated at $37^{\circ}$ for 1 hour (19). The assay mixture contained the following: $1.5 \mathrm{ml}$ substrate, $0.1 \mathrm{ml} 4 \%$ (vol) vol) Triton $X-100$, and the sample plus distilled water to make a final volume of $2 \mathrm{ml}$. Duplicate samples were incubated for 1.5 and 3 hours at $37^{\circ}$, and the reaction was stopped with $5 \mathrm{ml} 5 \%$ trichloroacetic acid $\left(4^{\circ}\right)$. Finally the mixture was filtered through Whatman 1 paper at $4^{\circ}$. The Folin-Ciocalteu reagent was diluted $1: 2.5$, and $1 \mathrm{ml}$ of this plus $5 \mathrm{ml}$ of $0.4 \mathrm{M} \mathrm{NaOH}$ were added to $1-\mathrm{ml}$ aliquots of filtrate. The tube was agitated on a Vortex-type mixer, and exactly 5 minutes later the optical density was read at $660 \mathrm{~m} \mu$. The difference between readings in the 1.5- and 3-hour incubation samples was used to calculate the tyrosine equivalents released in 90 minutes from a tyrosine calibration curve. For the calibration curve, a range of 0 to $1.5 \mu$ moles tyrosine was used. The units were tyrosine equivalents (micromoles) released per hour.
Catalase. The procedure devised by Baudhuin and associates (20) was employed with modifications (19). The substrate $\left(\mathrm{H}_{2} \mathrm{O}_{2}\right)$ was diluted in $0.02 \mathrm{M}$ imidazole-

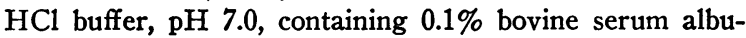
min. The concentration of hydrogen peroxide in the final substrate mixture was $0.8 \mathrm{mmole}$ per $\mathrm{L}$. To $0.1 \mathrm{ml}$ of the undiluted particle suspension, $0.1 \mathrm{ml}$ of $0.5 \%$ (vol/ vol) Triton X-100 was added. The substrate $(5 \mathrm{ml})$ was added and the mixture held at $0^{\circ}$ for 10 minutes. The reaction was stopped with $3 \mathrm{ml}$ titanium sulfate solution, and readings were made at $420 \mathrm{~m} \mu$ at room temperature. Tissue blanks substituting $5 \mathrm{ml}$ buffered albumin for substrate were included and the values obtained subtracted from assay values (19). The titanium sulfate solution was prepared by boiling $1.7 \mathrm{~g}$ in $500 \mathrm{ml} 2 \mathrm{~N}$ $\mathrm{H}_{2} \mathrm{SO}_{4}$. After cooling to room temperature, the suspension was centrifuged and the supernatant diluted with one-half its volume of $2 \mathrm{~N} \mathrm{H}_{2} \mathrm{SO}_{4}$ (19). Calculations were based on first order kinetics of the reaction. Units per sample assayed were expressed as log (OD "zero") OD test $) \times(1 / t)$, where $t=10$ minutes and "zero" represents the initial $\mathrm{H}_{2} \mathrm{O}_{2}$ concentration measured in a tube containing all reagents but devoid of particles.

Lactic dehydrogenase. The method of Wróblewski and LaDue (21), slightly modified, was employed. The total volume of the reaction mixture was $3 \mathrm{ml}$. Sigma reagents, including preweighed vials of DPNH $(0.2 \mathrm{mg})$, were used. One unit of activity equaled a decrease in $\mathrm{OD}$ of 0.001 per minute.

Coagulation tests. Studies were carried out either immediately after particle separation or after a brief period of storage. In some instances, the particles were washed with $0.25 \mathrm{M}$ sucrose immediately before use and the pellets suspended in $1 \mathrm{ml}$ imidazole-buffered saline (undiluted specimen). The thromboplastin generation test (TGT) was performed as previously described (22).

The Russell viper venom (Stypven) test was carried out as follows: Citrated blood was centrifuged at $1,400 \times$ $g$ for 20 minutes at $5^{\circ}$ and the upper two-thirds of the plasma layer used. Stypven was reconstituted in imidazole-buffered saline to a dilution of $1: 100,000$. Crude brain cephalin at a dilution of $1: 400$ (imidazole-buffered saline) served as control. The test material and substrate plasma were incubated in $0.1-\mathrm{ml}$ amounts for 30 seconds at $37^{\circ}$ with gentle agitation at 5-second intervals. One-tenth ml Stypven, followed by $0.1 \mathrm{ml} 0.025 \mathrm{M} \mathrm{CaCl}_{2}$, was then added. The cephalin control value was 10 seconds.

The partial thromboplastin time (PTT), utilizing kaolin, ${ }^{11}$ was carried out according to standard techniques (23-25). The fraction to be tested was added in $0.09-\mathrm{ml}$ amounts to $0.01 \mathrm{ml}$ kaolin stock suspension in a $12-\times 75$ $\mathrm{mm}$ test tube. One-tenth $\mathrm{ml}$ citrated plasma was added and the mixture incubated for exactly 10 minutes, with periodic agitation. Finally, $0.1 \mathrm{ml} 0.025 \mathrm{M} \mathrm{CaCl}_{2}$ was added and the clotting time recorded. The cephalin con-

11 N.F. colloidal, Mallinckrodt Chemical Works, St. Louis, Mo. 
trol reagent was prepared with the kaolin stock solution in a similar manner. Control values were 36 seconds.

Lipid extraction. The method of Folch, Lees, and Sloane Stanley (26) was employed. With this technique the sucrose was washed out, as evidenced by its lack of appearance on thin-layer chromatographic plates. The upper phase of the Folch wash was taken to dryness, dissolved in distilled water, and dialyzed. Phosphorus analysis (22) of the undialyzable material indicated that less than $1 \%$ of the lipid phosphorus was lost during extraction. The procedure has been described in detail (27).

\section{Results}

\section{Ultracentrifugation}

After density gradient ultracentrifugation the components of the homogenate reached equilibrium, and efficient separation was achieved. Figure 1 is a photograph of a $5-\mathrm{ml}$ gradient tube at the conclusion of the procedure. The two main particulate bands were examined by electron microscopy. The lower heterogeneous layer (density range, 1.21 to 1.17 ) consisted of platelet granules, mitochondria, and larger membrane fragments, but no "intact" platelets. This granule band was separated by a clear space from the upper membrane band (density range, 1.13 to 1.12 ), which appeared homogeneous. The top of the gradient consisted of scattered membranes, solubilized enzymes, and lipoprotein material.
Electron micrographs of the membrane and granule layers derived from a 5-minute homogenate are shown in Figures 2 and 3, respectively. The duration of the homogenization procedure affected the ultrastructural appearance of individual platelet fractions. Homogenization for 10 minutes yielded membranes that were not contaminated by any recognizable organelles or fragments of platelet cytoplasm. However, the granule band showed considerable distortion, some rupture, and swollen mitochondria. A 5-minute homogenization procedure preserved the integrity of the granules and mitochondria, and contamination with platelet "ghosts" was avoided. However, a few large membrane fragments ranging from 0.4 to $1.0 \mu$ in length were present in this fraction. Since such fragments seemed to have a tendency to round up, they looked like empty platelet granules. The membrane fractions obtained from the 5-minute specimen did not seem to be as "clean" as those of the 10-minute sample, since electron dense material was still attached to some of them. Homogenization of less than 5 minutes proved to be unsatisfactory from a morphological standpoint. The organelles in the granule band of such specimens were well preserved, but the fraction was contaminated with some large platelet fragments as well as occasional platelet ghosts. The membrane band of this specimen was also unsatisfac-

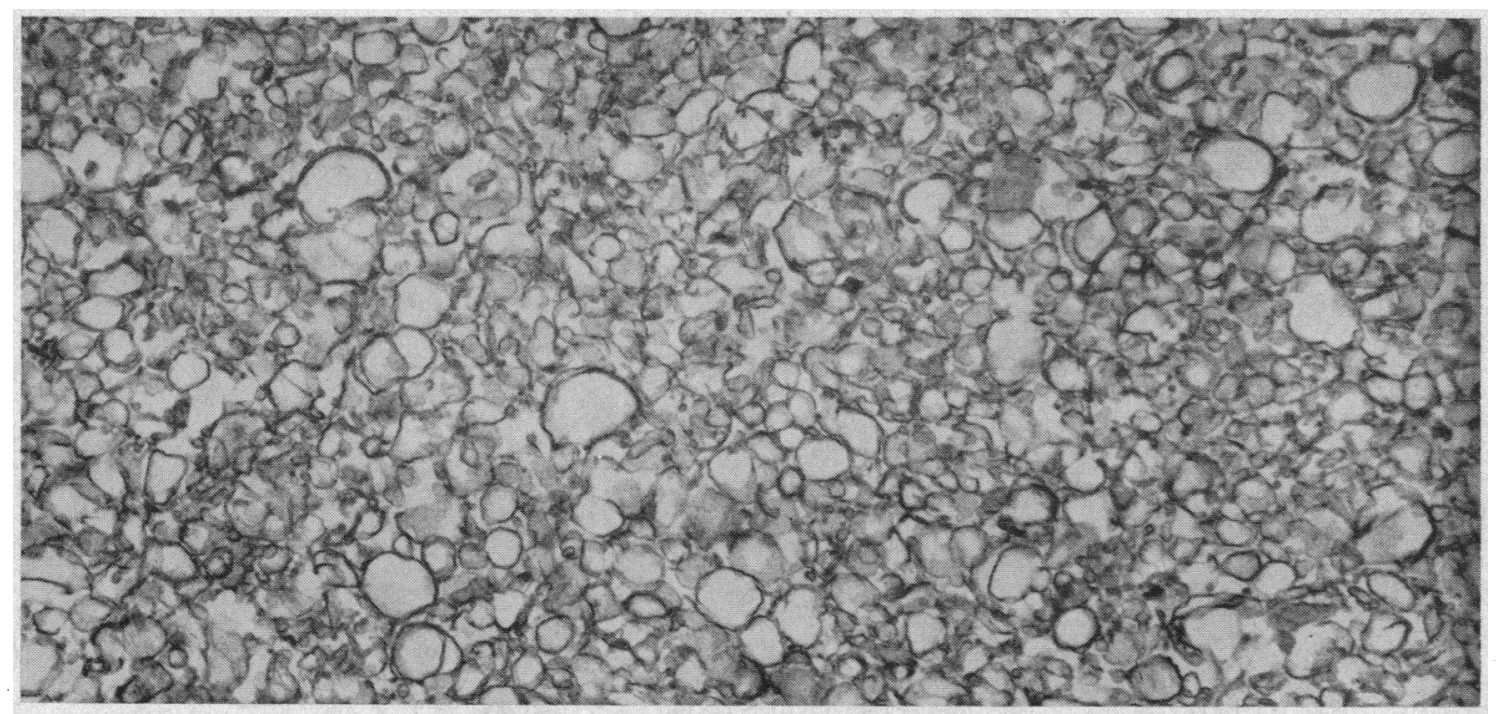

Fig. 2. Representative electron miCrograph of MEmbrane fraction. Note the absence of formed organelles. Grey background material is believed to consist of soluble platelet proteins precipitated by the fixative. $\times 30,000$. 


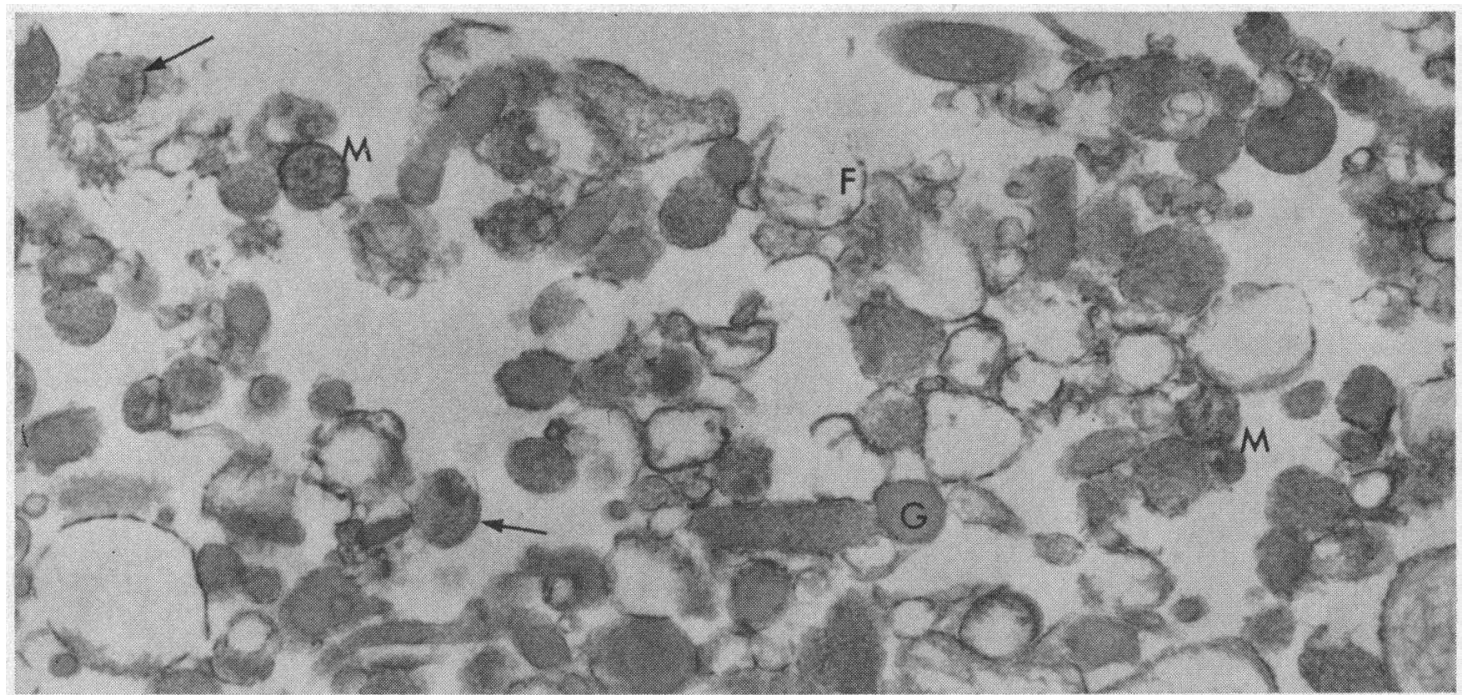

Fig. 3. Representative electron micrograph of GRANUle fraction. Note that membranes surrounding most granules have remained intact. Large membrane fragments $(F)$ suggest their origin from ruptured granules. G, granule; M, mitochondrion. Arrows point to two "bull's eye" granules. $\times 30,000$.

tory, since some platelet cytoplasm was still observed to be attached.

The amount of material in each fraction was also related to the time of homogenization. Since it was not possible to completely disrupt all platelets without damaging intracellular organelles, the initial discarded sediment necessarily contained both whole and partially disrupted platelets that released variable amounts of soluble and particulate components. A 5-minute homogenization time was selected only because it yielded reasonable amounts of morphologically satisfactory subcellular material. These considerations are illustrated in Table I, where the results of protein and enzyme recoveries from 2 - and 5-minute homogenates, simultaneously prepared from identical quantities of platelets, were compared. Increases in protein recovery in fractions derived from a 5minute homogenate over recoveries resulting from a 2-minute homogenate differed in each fraction. Although the granule protein increased 1.7 times, there was a twofold rise in membrane recovery, and the soluble fraction was 1.4 times higher. If the initial discarded sediment consisted of intact platelets only, the relative increases in the fractions of the 5-minute homogenate should have

TABLE I

$A$ comparison of protein and enzyme recoveries from 2- and 5-minute homogenates

\begin{tabular}{|c|c|c|c|c|c|}
\hline & Sediment & Granules & Membranes & $\begin{array}{l}\text { Soluble } \\
\text { fraction }\end{array}$ & $\begin{array}{c}\text { Total } \\
\text { recovery }\end{array}$ \\
\hline \multirow{3}{*}{$\begin{array}{l}2 \text { minutes } \\
\text { Protein } \\
\text { Catalase + Triton } \\
\text { Acid phosphatase } \\
\text { Acid phosphatase } \\
\quad+\text { Triton }\end{array}$} & $\% *$ & $\%$ & $\%$ & $\%$ & $\%$ \\
\hline & $\begin{array}{r}49.6 \\
7.9 \\
54.9\end{array}$ & $\begin{array}{r}12.6 \\
5.5 \\
17.4\end{array}$ & $\begin{array}{l}2.1 \\
3.5 \\
1.9\end{array}$ & $\begin{array}{l}34.2 \\
62.9 \\
13.7\end{array}$ & $\begin{array}{l}98.5 \\
79.8 \\
87.9\end{array}$ \\
\hline & 44.4 & 38.7 & 3.1 & 9.9 & 96.1 \\
\hline \multirow{2}{*}{$\begin{array}{l}5 \text { minutes } \\
\text { Protein } \\
\text { Catalase + Triton } \\
\text { Acid phosphatase } \\
\text { Acid phosphatase } \\
\quad+\text { Triton }\end{array}$} & $\begin{array}{r}18.9 \\
2.2 \\
16.8\end{array}$ & $\begin{array}{r}22.0 \\
6.6 \\
42.4\end{array}$ & $\begin{array}{l}4.3 \\
4.7 \\
8.0\end{array}$ & $\begin{array}{l}47.6 \\
79.9 \\
28.5\end{array}$ & $\begin{array}{l}92.8 \\
93.4 \\
95.7\end{array}$ \\
\hline & 15.4 & 61.9 & 8.6 & 20.8 & 106.7 \\
\hline
\end{tabular}

$* \%=$ amount in each fraction $/($ sediment + homogenate $)$. 


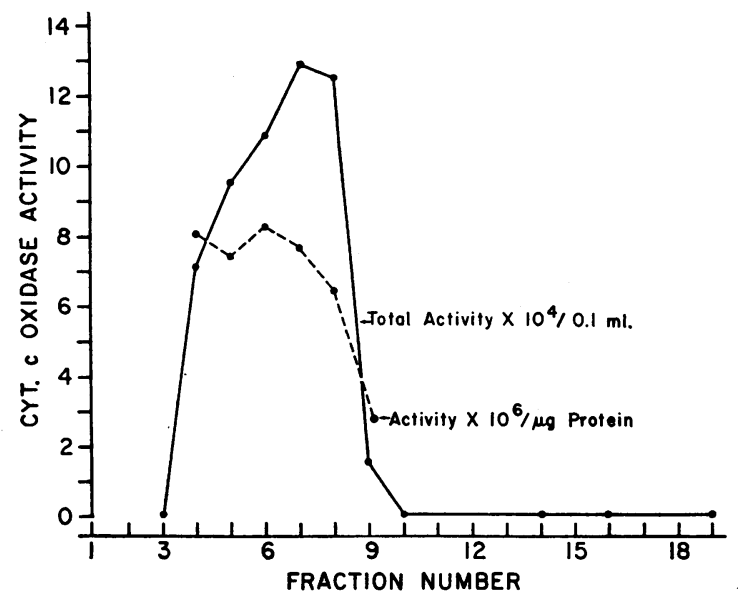

Fig. 4. Distribution of cytochrome c oxidase acTIVITY IN SUBCELLULAR PLATELET PARTICLES. Activity of this mitochondrial enzyme was found only in the granules. In terms of specific activity, the lower portion of the granule band predominated.

been the same when compared with the 2-minute homogenate, but this did not occur. The inability to prepare a "perfect" homogenate influenced the absolute per cent of enzyme recovery in the subcellular fractions, since varying amounts were lost in the initial sediment.

\section{Cytochrome c oxidase}

Activity of this mitochondrial enzyme was confined to the granule layer and was absent from all other components of the gradient. In terms of specific activity (activity per milligram of pro-

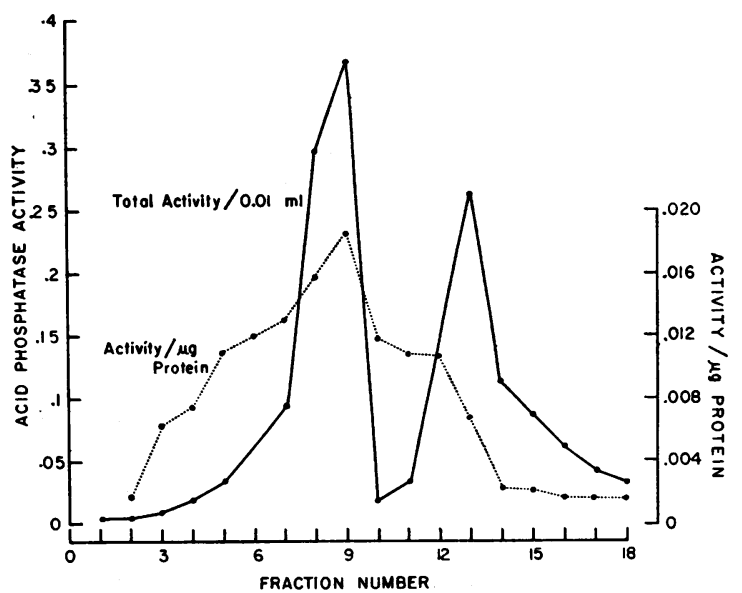

Fig. 5. ACID Phosphatase activity in SUbCEllular PLATELET FRACTIONS. Enzyme activity is shown in relationship to protein distribution. Specific activity was highest in the upper portion of the granule band, which was in contrast to cytochrome c oxidase.

tein), higher values were found at the bottom of the granule band. Results are shown in Figure 4.

\section{Acid phosphatase}

The major particulate site of acid phosphatase activity was the platelet granules. The highest specific activity was found at the top of the granule layer. Activity was also found in the top section of the gradient, which contained soluble components and scattered membranes. Results of enzyme assays on fractions from the entire gradient are depicted in Figure 5.

TABLE II

Subcellular distribution of enzymes studied*

\begin{tabular}{|c|c|c|c|c|}
\hline Enzyme & $\begin{array}{c}\text { No. of } \\
\text { experiments }\end{array}$ & Granules & Membranes & Soluble fraction \\
\hline Acid phosphatase & $\begin{array}{l}6 \\
(6) \dagger\end{array}$ & $\begin{array}{c}\text { \% } \\
51.1 \stackrel{7.2}{ \pm} \\
(60.2) \pm 10.7\end{array}$ & $\begin{array}{c}\% \\
16.0^{\%} \pm 9.5 \\
(17.0) \pm 8.5\end{array}$ & 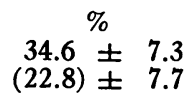 \\
\hline Beta-glucuronidase & 2 & $38.6 \pm 8.7$ & $7.9 \pm 0.5$ & $53.6 \pm 8.2$ \\
\hline Cathepsin & $\begin{array}{c}1 \\
(2)\end{array}$ & $\begin{array}{l}58.1 \\
(61.7)\end{array}$ & $\begin{array}{l}2.5 \\
(1.9)\end{array} 2.6$ & $\begin{array}{l}39.5 \\
(36.5) \pm 13.2\end{array}$ \\
\hline Catalase & $\begin{array}{c}1 \\
(3)\end{array}$ & $\stackrel{2.6}{(6.5)} \pm 1.7$ & $\stackrel{3.2}{(5.3)} \pm 0.4$ & $\stackrel{94.3}{(88.2)} \pm 1.2$ \\
\hline Lactic dehydrogenase & 1 & 2.0 & 0.2 & 97.8 \\
\hline
\end{tabular}

* Results are reported as a percentage of the sum of recovered activity. Values given refer to the means \pm the standard deviations.

$\dagger$ The values in parentheses indicate assays performed in the presence of Triton $X-100$. 

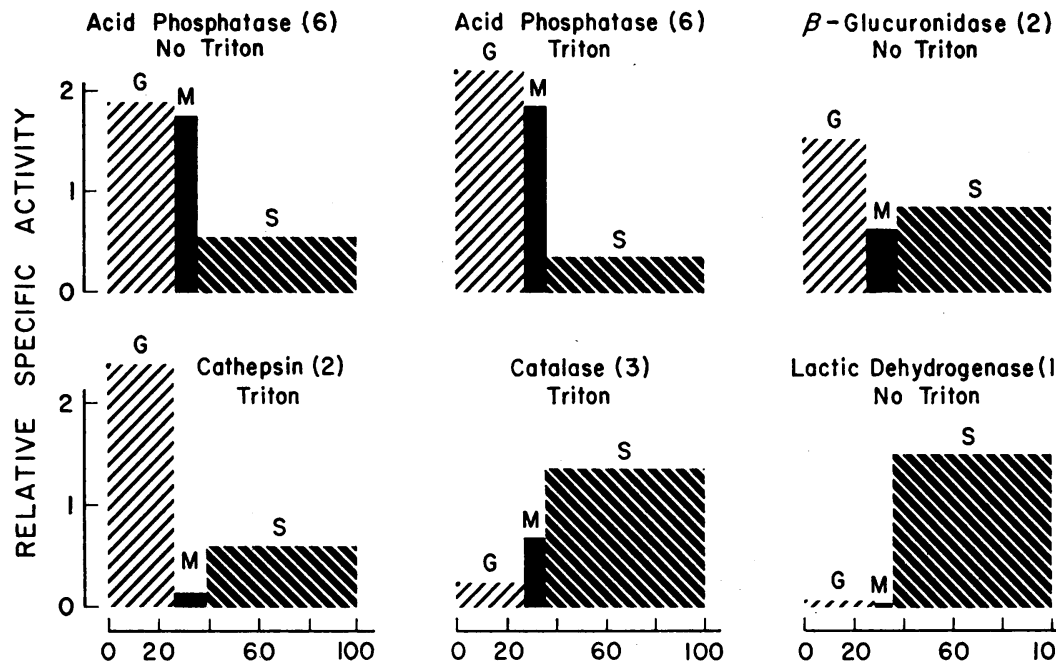

Catalase (3) Triton

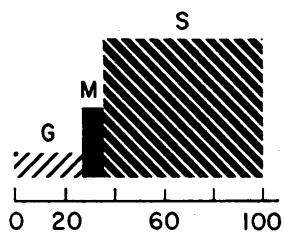

Lactic Dehydrogenase (1) No Triton

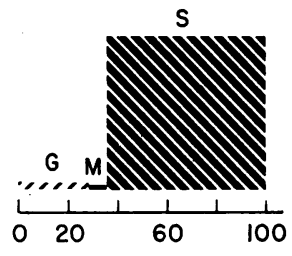

Fig. 6. Distribution of enzymes in subcellular platelet fractions. The ordinate represents the mean relative specific activity (percentage of total activity/ percentage of total protein), and the abscissa percentage of total protein (29). The area of each bar is proportional to the percentage of activity recovered in the corresponding fraction, and its height indicates the degree of purification above the homogenate (which is represented by unity). There was about a twofold purification of acid phosphatase in the granules and almost that amount in the membranes. G, granules; M, membrałes; S, soluble fraction. Numbers in parentheses refer to the number of experiments performed.

To distinguish between particulate and soluble sources of acid phosphatase activity, we divided the contents of each gradient tube into two portions, one containing granules and the other membranes and soluble material. The division was made at the level of tube 10 (see Figure 5). The granules and membranes were washed and the homogenized pellets and supernatants reassayed. These manipulations resulted in variable losses of enzyme activity ranging from 4 to $10 \%$ when calculated as a fraction of the material originally placed on the gradient. The granule wash contained faint traces of protein and no enzyme activity, but the membranes and the soluble protein with which they previously overlapped were both active.

Enzyme distribution in components of the gradient as a percentage of the sum of recovered activity is shown in Table II. Some of the soluble activity could have been derived from damaged granules or membranes, or it might have represented a soluble nonlysosomal acid monoester phosphohydrolase similar to that described in other animal tissues (28). The results are further illustrated in Figure 6 (29).
Studies were undertaken to determine whether the platelet granules demonstrated biological properties attributed to "classical" lysosomes, namely, that certain physical manipulations result in increases in release of enzyme activity (30). For example, two aliquots of the same platelet suspension were homogenized for 2 and 5 minutes, respectively, and the granules isolated therefrom compared with respect to enzyme units per milligram of protein. The "free" activities $(31,32)$ (as assayed in $0.25 \mathrm{M}$ sucrose for 10 minutes at $37^{\circ}$ ) were 9.0 and $8.8 \mathrm{U}$, respectively, demonstrating that the increase in homogenization time did not enhance enzyme availability. In another experiment, granules derived from a 3-minute homogenate were rehomogenized, and no increase in free activity was found. Other procedures for particle disruption, such as treatment in a Waring blendor, repeated freezing and thawing, and ultrasonic disruption ${ }^{12}$ were also without effect. Therefore, the platelet granules did not respond to physical trauma by an increase in acid phos-

\footnotetext{
12 Branson model S-75, Heat Systems Co., Melville, N. Y.
} 
phatase activity and in this sense were not "classical" lysosomes.

When assays were performed in the absence of "osmotic protection" $(31,32)$ of $0.25 \mathrm{M}$ (isotonic) sucrose in the substrate, there was 1.2 to 1.5 times more acid phosphatase activity than found in its presence. This difference occurred only in granule and membrane fractions and was unrelated to storage. Experiments were performed to determine whether the higher values obtained without isotonic sucrose were due to release of enzymes from "unprotected" particles. Granules were incubated under the usual assay conditions, with and without osmotic protection, but in the absence of substrate. Samples were assayed for free activity, and the values were identical. Therefore, there was no increase in free activity in the tube that was initially incubated without osmotic protection. On the other hand, when the preincubated granules were assayed in the regular manner (without addition of isotonic sucrose to the substrate), there was a 1.3 -fold increase in activity. Thus, the action of sucrose could not be explained by osmotic protection, but probably by an inhibitory effect on the interaction between substrate and particle-bound enzymes.

The effect of the nonionic detergent, Triton $\mathrm{X}-100^{13}$ (alkyl phenoxy polyethoxy ethanol), on enzyme activity was studied (33). It was added to the assay mixture before incubation, in a predetermined final concentration of $0.125 \%$ (vol/ vol). The presence of EDTA in some incubation mixtures reduced the effectiveness of Triton, and whenever possible it was omitted. The specific activity of acid phosphatase in the granules increased from a mean of $13.6 \mathrm{U}$ per $\mathrm{mg}$ protein to $27.3 \mathrm{U}$. The increase in the membranes was from 12.2 to 23.9 , and the value for the homogenate was 6.5 to 12.1. However, little or no change occurred in the soluble fraction (3.4 to 4.2).

The Triton effect was further investigated to ascertain whether the increases in activity represented solubilized enzyme. Granules were diluted $1: 5$ in $0.25 \mathrm{M}$ sucrose (no EDTA) containing $1.5 \%$ Triton (vol/vol). A similar dilution with no Triton was prepared, and both were incubated at $37^{\circ}$ for 10 minutes. Aliquots of the Tritoncontaining incubation mixture were ultracentri-

13 Rohm and Haas, Philadelphia, Pa. fuged at $39,400 \mathrm{rpm}$ for 20 minutes. The supernatant fluid and pellet contained 11 and $66 \%$, respectively, of the activity in a similar uncentrifuged sample. Despite the loss of activity due to manipulation, the centrifuged pellets from Triton-treated granules contained 1.4 times more activity than was present in the total untreated granule sample. Thus, the usual increase with Triton was obtained, but only $11 \%$ of the total enzyme activity was recovered in soluble form.

An attempt was made to determine whether the Triton effect resulted from a direct interaction between detergent and particles, or whether it was similar to sucrose, taking place only in the presence of substrate. Granules were preincubated with Triton (with lowest concentration to give maximal effect) for 10 minutes, and an aliquot was assayed for free activity without adding Triton to the final assay system. The assay value of the Triton-treated granules was 1.6 times greater than that of a comparable control that was not pretreated with Triton. This indicated that the Triton effect took place during the preincubation period, and not during the assay procedure, suggesting a direct effect on the particles.

\section{Beta-glucuronidase}

When gradient fractions were assayed as in Figure 5, the highest specific activities in the granule band for both acid phosphatase and $\beta$-glucuronidase occurred in the same tube. Distribution of the enzyme is shown in Table II and Figure 6. Treatment of the granules with Triton X-100 resulted in a 1.7-fold increase in activity, but assays of the soluble form were unaffected.

\section{Cathepsin}

The activity of this enzyme was weak, necessitating large aliquots for measurement and prolonged incubation times, which may have introduced inaccuracies. Recovery experiments indicated that the granule layer accounted for more than half of the cathepsin activity (Table II). Relatively little enzyme was associated with the membranes (Figure 6). Treatment with Triton $\mathrm{X}-100$ resulted in a twofold increase in the activity of the granules, a 2.4-fold increase in the membranes, and no effect on the soluble fraction. 


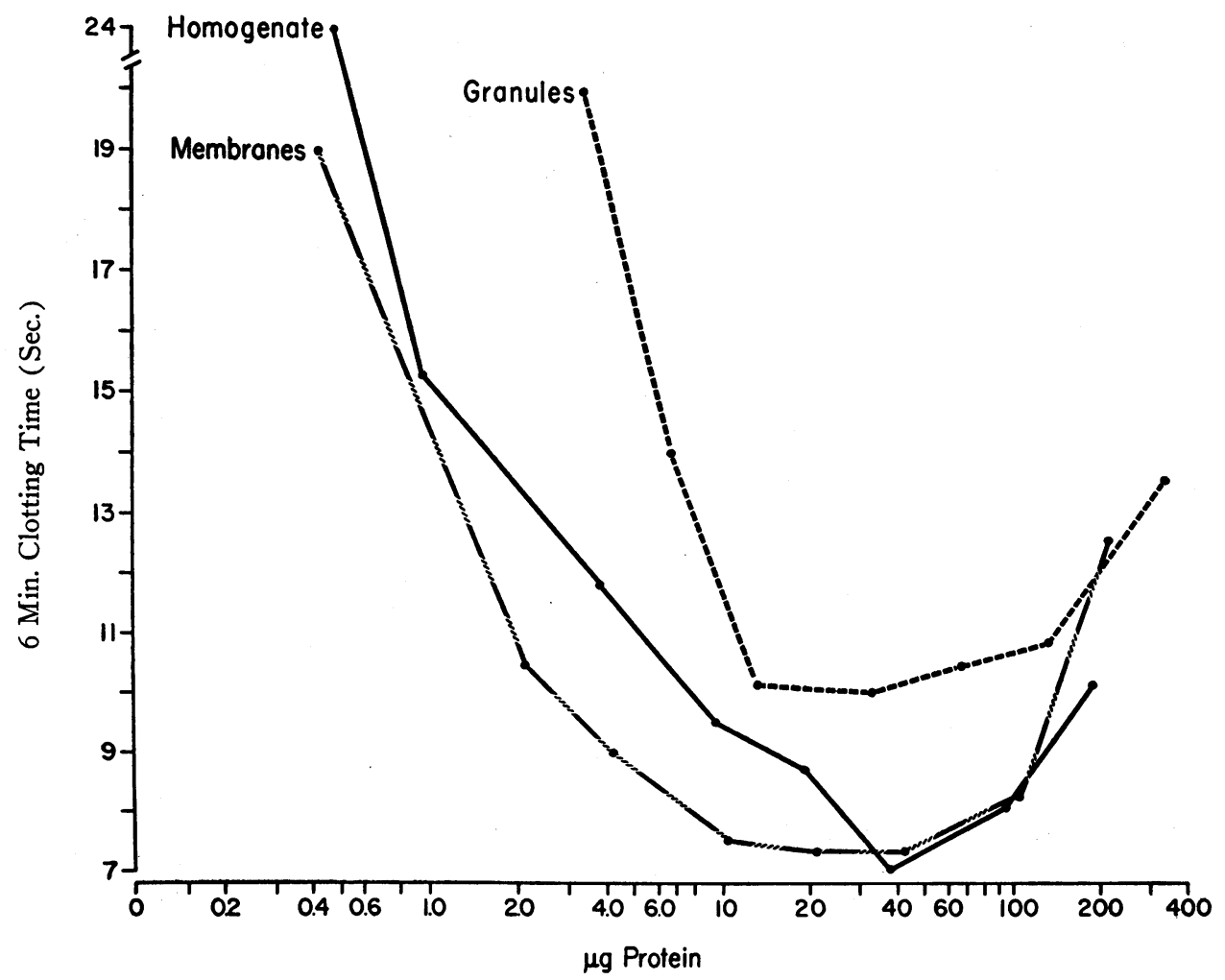

Fig. 7. Subcellular platelet particles in the thromboplastin generation test. The platelet membranes and original homogenate had shorter 6-minute substrate clotting times than platelet granules at comparable protein concentrations.

\section{Catalase}

In contrast to the acid hydrolases, only small amounts of catalase were recovered in granule and membrane fractions. Most of the activity appeared in soluble form (Table II, Figure 6). The distribution pattern persisted despite reduction of homogenization time from 5 to 2 minutes. Triton treatment caused twofold increases in granule and membrane activity and had a negligible effect on the soluble material.

Effects of homogenization on the release of platelet catalase and acid phosphatase are compared in Table I. After 2 minutes of platelet homogenization, about one-half of the acid phosphatase and total protein was found in the discarded sediment. Only $8 \%$ of the catalase was in this sediment, and $63 \%$ was released into the soluble fraction. These differences persisted in the 5-minute homogenate.

\section{Lactic dehydrogenase}

In contrast to the enzymes found in particulate fractions, $98 \%$ of the lactic dehydrogenase activity was soluble (Table II and Figure 6), suggesting that it was a "cytoplasmic" enzyme, unassociated with intracellular organelles.

\section{Blood coagulation studies}

A) Thromboplastin generation test (TGT). In this system the platelet granules, membranes, and homogenate were compared with respect to the amount of protein required to give a specific clotting time after 6 minutes of incubation. The membranes and homogenate showed similar activity, which exceeded that of the granules. These differences were more marked if the particles were tested immediately after fractionation. Since the granules at this point were in concentrated sucrose, and EDTA was present, experiments were also carried out on washed fractions. After washing, activity of both the membranes and granules increased in a proportionate manner. It is not clear whether it was the additional manipulations or merely removal of sucrose and EDTA that was responsible for this increase. Nevertheless, 
there was no instance in which the general pattern was altered. At comparable protein concentrations, the granules lagged behind the membranes and homogenate and showed a sharp drop in activity with increasing dilution. A typical experiment is shown in Figure 7.

To determine whether the lipid component of the particles contributed to the observed differences in clotting activity, lipid extraction was performed on the granules, membranes, and whole platelets. The amount of lipid phosphorus in the incubating mixture was measured and plotted against the clotting time obtained after 6 minutes. The differential between granules and membranes was no longer present when their constituent lipids were tested. Optimal activity occurred at identical phosphorus concentrations. We concluded that the lipid moiety of the membranes and granules was not responsible for observed differences in their coagulation properties.

It was possible to calculate and compare the amount of phospholipid required for an 11-second
TABLE III

Lipid requirement for 11-second substrate clotting time in the thromboplastin generation test

\begin{tabular}{lc}
\hline Component tested & Lipid phosphorus \\
\hline & $\mu g$ \\
Granule particles & 5 \\
Granule lipid & 17.5 \\
Membrane particles & 0.9 \\
Membrane lipid & 20 \\
Homogenate particles & 2.7 \\
Platelet lipid & 15 \\
\hline
\end{tabular}

clotting time when it was present as lipoprotein in the subcellular particle and when it was in the form of extracted lipid. This is shown in Table III. The clot-promoting property of platelet phospholipid linked with protein was more effective than the lipid alone.

The soluble component at the top of the gradient showed clotting activity comparable to that found with the membranes, and it persisted after prolonged ultracentrifugation. Because of its

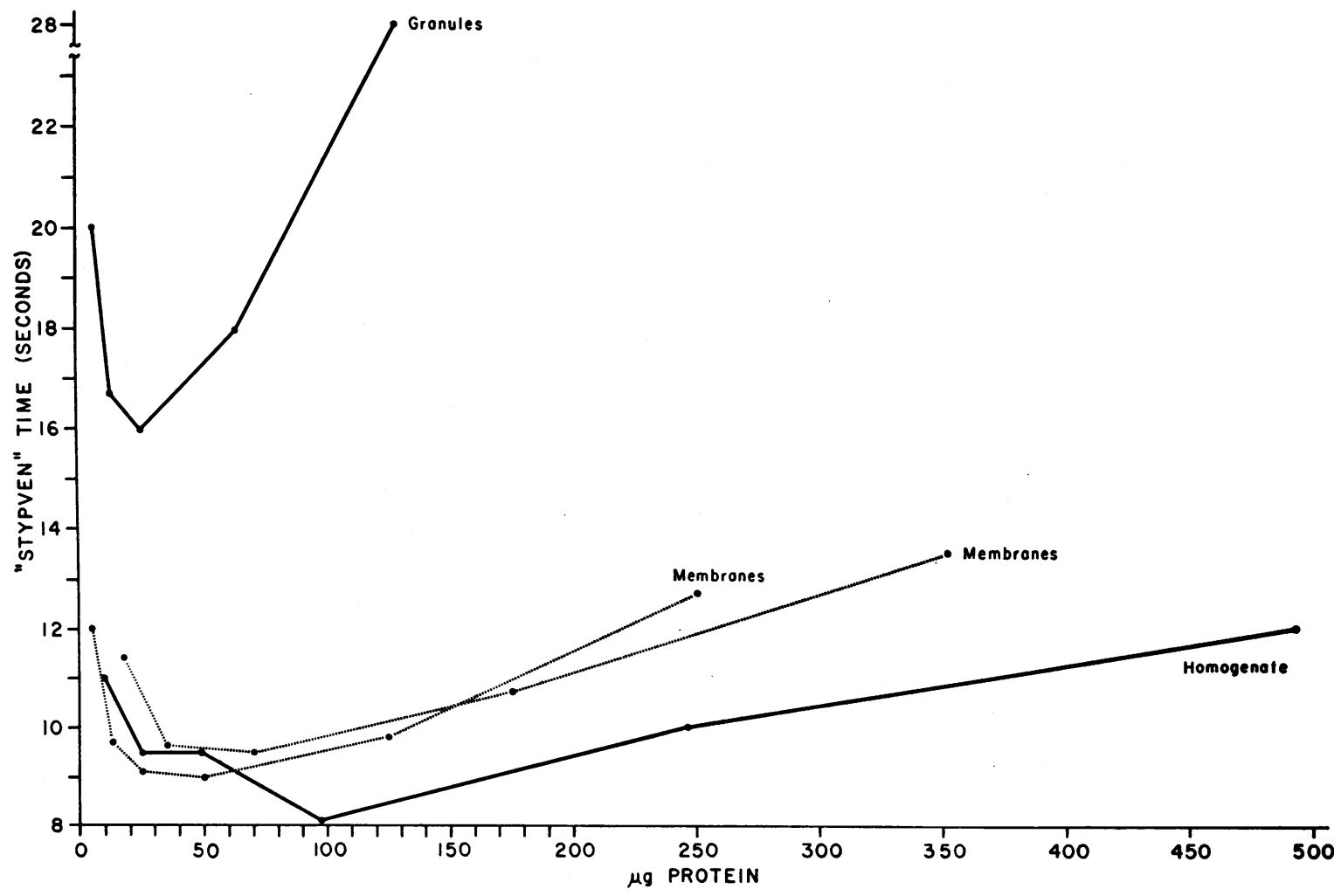

Fig. 8. Comparison between platelet granules and membranes in the Stypyen test. The membranes and homogenate showed similar responses, whereas the Stypven times of the granules were longer. In general, the differences were less pronounced than in the thromboplastin generation test. 


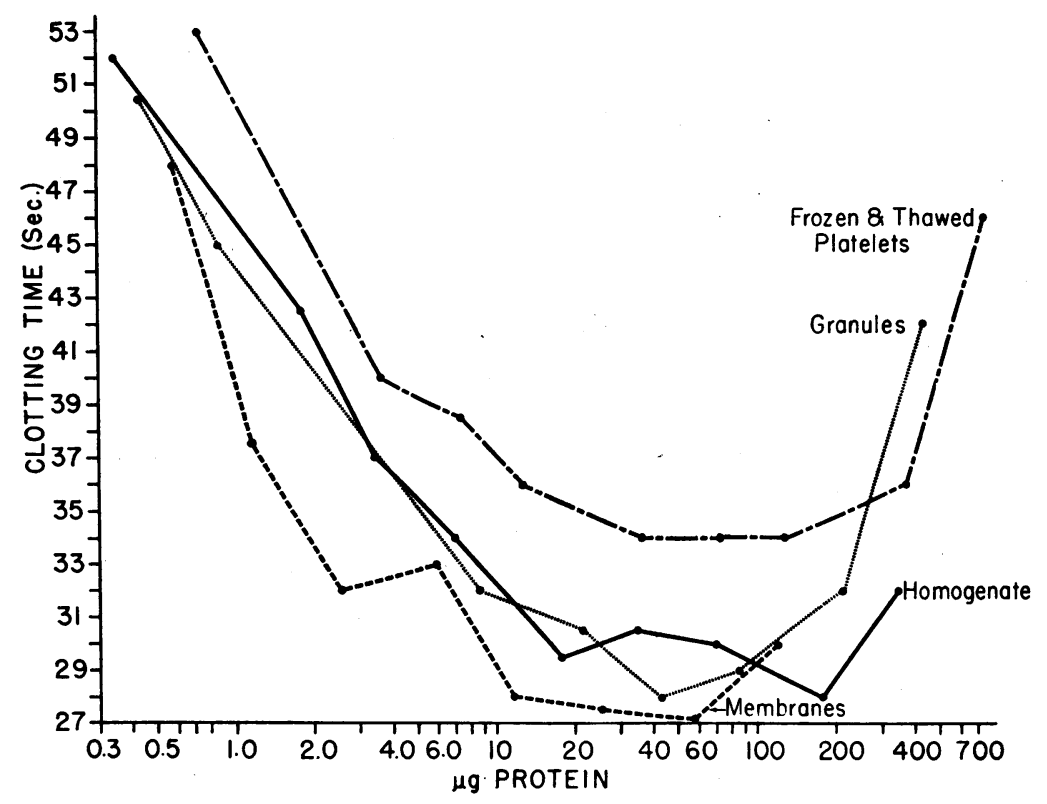

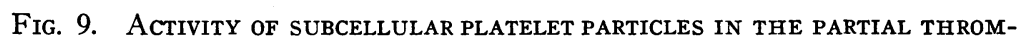
BOPLASTIN TIME TEST. Differences were least striking in this system, but the efficiency of the granules did not exceed that of the membranes.

heterogeneous nature, no further studies were carried out.

B) Stypven test. Results with the Stypven time were comparable to those in the TGT. At similar protein concentrations, the clotting times obtained with the granules were consistently longer than those obtained with the membranes and homogenate. An experiment is depicted in Figure 8. On repeated testing, the results with fractions sometimes showed less of a differential, but at no time did the activity of the granules exceed the homogenate or membranes. Removal of the lipid moiety and retesting produced the same results as obtained with the TGT. The differential between particles was lost, and identical amounts of lipid phosphorus were needed for comparable clotting times.

C) Partial thromboplastin time (PTT). Differences between the granules and membranes were least striking in this system. There was only a slight, but consistent, lag of granule activity behind that of the membranes in three separate experiments. As shown in Figure 9, both subcellular fractions and the homogenate were more active than a control consisting of frozen and thawed platelets.

\section{Discussion}

Sucrose gradient ultracentrifugation of platelet homogenates has made it possible to study their major cytoplasmic components. These consisted of mitochondria, other granules, at least some of which were probably lysosomes, and membranes. Although the necessarily high sucrose concentrations presented certain practical and technical disadvantages, such as high viscosity and hypertonicity (34), they allowed the granules to reach density equilibrium without sedimenting and permitted separation from the membranes. The origin of the soluble components at the top of the gradient is difficult to assess, and this problem has been alluded to by others (34 36). Although some of the material may have originally been soluble in the intact platelet, it may also have been liberated by damaged particles during homogenization.

Cytochrome c oxidase, an enzyme found only in mitochondria, was a principal cytoplasmic "marker." Its localization in the granule band, but not in the membranes, was further evidence of efficient separation of these particles. The relative specific activity of cytochrome $\mathrm{c}$ oxidase in the entire granule band was 3.8 (with the ho- 
mogenate taken as 1), indicating a high degree of purification. Tube 6 (Figure 4 ) had a relative specific activity of 4.4 , indicating that samples of granules from the lower portion of the band had the highest ratio of mitochondria to other granules.

Acid phosphatase was studied in detail for several reasons: a) Zucker and Borrelli (37) and others have demonstrated the presence of this enzyme in human platelets. $b$ ) It has been used as a marker for lysosomes by De Duve (30) and associates. c) Electron microscopic observations on platelets during clotting by Parmeggiani (38) and Rodman, Mason, and Brinkhous (39) indicated that the granules disappear in the process. Firkin, O'Neill, Dunstan, and Oldfield have shown that they also disappear after storage (40). Giudici and Turazza $(41,42)$, Rodman and associates (39), and Firkin (43) have previously suggested that platelet granules may be lysosomes. In the present study, the highest specific activity of acid phosphatase was in a portion of the granule band above the area of greatest specific activity of cytochrome c oxidase, indicating the presence of particles other than mitochondria and suggesting that they were lysosomes.

Studies on the influence of Triton X-100 on enzyme activity were of interest. This detergent produced a twofold increase in assay values of all particle-bound enzymes. When the Triton-treated granules were ultracentrifuged, only $11 \%$ of the activity present in an uncentrifuged sample was found in the supernatant. Although there may have been enzyme release followed by irreversible adsorption to the particles (44), this was considered unlikely. It appeared that the increase in activity mediated by Triton represented a form of activation other than solubilization.

Beta-glucuronidase, another lysosomal enzyme (45), was present in the granule band, but the differences in distribution between this enzyme and acid phosphatase indicated that it was less firmly bound to the particles. Alternatively, these differences could have been due to the presence of nonlysosomal $\beta$-glucuronidase (30). Assay of cathepsin, the third lysosomal enzyme studied, presented certain inherent difficulties (45); nevertheless, it was well localized in the granule layer and effectively purified on the sucrose gradient.

Thus, three acid hydrolytic enzymes have been found in association with platelet granules. These data, along with the evidence for structure-linked latency provided by Triton $\mathrm{X}-100$, suggest that the granule fractions contain lysosomes. However, their lack of response to various types of physical trauma differed from the properties of lysosomes as classically defined (30). On the other hand, lysosomes with properties similar to those of platelet granules have been described in tissues other than rat liver (30). Furthermore, the lysosome concept as originally proposed has already been expanded to include several distinct acid phosphatase-containing subcellular structures $(30,46,47)$. Some of these organelles contain acid phosphatase in or near their delimiting membrane $(46,47)$.

The main reason for studying catalase was the morphological similarity between so-called "bull's eye" platelet granules and microbodies (20, 48$50)$. The microbodies have been defined as nonlysosomal particles that contain urate oxidase, D-amino acid oxidase, and catalase. From the data obtained in these studies, it can be said that a small amount of catalase was associated with platelet granules, but no other correlation is possible. Lactic dehydrogenase is known to be present in platelets in high concentration (51) and from our data appeared to be soluble. In a sense, it served as a control, indicating that all available enzymes were not bound in random fashion, i.e., the association of certain enzymes with the granules was not a chance occurrence.

The subcellular platelet particles were substituted for whole platelets in three clotting systems. The membrane fractions could replace platelets as efficiently as the original homogenate, whereas the granules were less effective. Differences were most pronounced in the TGT, somewhat less in the Stypven test, and only slight in the PTT. This may have been related to the prolonged (10-minute) incubation time in the PTT assay and was reminiscent of observations made on latex particles (52), which were inert as platelet substitutes unless incubated in plasma before testing. When the phospholipids were extracted from the particles, their effectiveness as platelet reagents was identical. Perhaps the lipoprotein of the platelet membrane is more "available" for interaction with plasma clotting factors than that of the granules. 
Since the soluble material at the top of the gradient was active, it is possible that there is soluble lipoprotein in the platelets that is capable of catalyzing prothrombin activation. It may represent "structural" lipoprotein, which ordinarily is not free in the intact platelet. Alternatively it could correspond to the nonsedimentable platelet Factor III (PF-3) described by Horowitz (53) or the thromboplastic cell component of Shinowara (54).

Electron microscopic observations on platelets during the coagulation process indicate that the membranes remain essentially intact during the formation of thrombin $(38,39)$. Platelet membranes may therefore provide the catalytic lipoprotein surface that enhances formation of the intrinsic prothrombin activator, and this is what is referred to as platelet Factor III. Precisely what makes the platelet membrane lipoprotein available under these circumstances is not known. It is probably not necessary to postulate release of granules or soluble material from the interior of platelets in order for them to function in the coagulation process.

Although the above speculations are based on information derived from subcellular particles that are in an unnatural physical state, their validity is enhanced by the recent observation that membranes retain their "inside-outside" orientation and net negative charge (55) when isolated. The finding that hydrolytic enzyme activity, fibrinogen (56), and serotonin (57) are associated with granules would lead us to suggest further that platelet granules function primarily as storehouses for enzymes and other metabolic substances, and not in the coagulation process.

\section{Summary}

1. Homogenates of human platelets were subjected to continuous sucrose gradient ultracentrifugation and separated into granule and membrane components.

2. The effectiveness of the homogenization process and the results of ultracentrifugation were evaluated by electron microscopy.

3. Acid hydrolytic enzyme activity (lysosomal) was associated with the platelet granules. This activity could be increased by treatment with Triton $\mathrm{X}-100$, but not by physical disruption of the granules.
4. The platelet granules and membranes were tested in three in vitro coagulation systems, and although the degree of effectiveness was variable, the platelet membranes were more efficient as clotpromoting agents than were the granules. When the lipids were extracted from the granules and membranes and tested, the differential was abolished and clot-promoting activity of granule and membrane lipid was the same. We concluded that the lipoprotein of platelet membranes was more "available" for interaction with coagulation proteins than was the lipoprotein from the granules.

5 . We suggest that platelet granules are primarily concerned with lysosomal and metabolic activities, and the platelet membranes furnish a catalytic surface for the formation of the intrinsic prothrombin activator.

\section{References}

1. Marcus, A. J., and M. B. Zucker. The Physiology of Blood Platelets: Recent Biochemical, Morphologic and Clinical Research. New York, Grune \& Stratton, 1965.

2. Zucker, M. B., and A. J. Marcus. Editorial: unanswered questions concerning functions of platelets. Nouv. Rev. franc. Hemat. 1965, in press.

3. Marcus, A. J., and D. Zucker-Franklin. Studies on subcellular platelet particles. Blood 1964, 23, 389.

4. Marcus, A. J., and D. Zucker-Franklin. Enzyme and coagulation activity of subcellular platelet fractions (abstract).' J. clin. Invest. 1964, 43, 1241.

5. Gaintner, J. R., D. P. Jackson, and E. W. Maynert. The action of thrombin on platelet 5-hydroxytryptamine. Bull. Johns Hopk. Hosp. 1962, 111, 185.

6. Luck, D. J. L. Formation of mitochondria in Neurospora crassa. A quantitative radioautographic study. J. Cell Biol. 1963, 16, 483.

7. Pease, D. C. An electron microscopic study of red bone marrow. Blood 1956, 11, 501.

8. Millonig, G. A modified procedure for lead staining of thin sections. J. biophys. biochem. Cytol. 1961, $11,736$.

9. Lowry, O. H., N. J. Rosebrough, A. L. Farr, and R. J. Randall. Protein measurement with the Folin phenol reagent. J. biol. Chem. 1951, 193, 265.

10. Miller, G. L. Protein determination for large numbers of samples. Analyt. Chem. 1959, 31, 964.

11. Luck, D. J. L. Personal communication.

12. Martin, A. P., H. A. Neufeld, F. V. Lucas, and E. Stotz. Characterization of uterine peroxidase. J. biol. Chem. 1958, 233, 206.

13. Smith, L. Cytochromes a, $\mathbf{a}_{1}, \mathbf{a}_{2}$, and $\mathbf{a}_{3}$ in Methods in Enzymology, S. P. Colowick and N. O. Kaplan, 
Eds. New York, Academic Press, 1955, vol. 2, p. 732.

14. Smith, L. Spectrophotometric assay of cytochrome c oxidase in Methods of Biochemical Analysis, D. Glick, Ed. New York, Interscience, 1955, vol. 2, p. 427.

15. Nielsen, S. O., and A. L. Lehninger. Phosphorylation coupled to the oxidation of ferrocytochrome $c$. J. biol. Chem. 1955, 215, 555.

16. Cooperstein, S. J., and A. Lazarow. A microspectrophotometric method for the determination of cytochrome oxidase. J. biol. Chem. 1951, 189, 665.

17. Fishman, W. H., B. Springer, and R. Brunetti. Application of an improved glucuronidase assay method to the study of human blood $\beta$-glucuronidase. J. biol. Chem. 1948, 173, 449.

18. Gianetto, R., and C. de Duve. Tissue fractionation studies. 4. Comparative study of the binding of acid phosphatase, $\beta$-glucuronidase and cathepsin by rat-liver particles. Biochem. J. 1955, 59, 433.

19. Berthet, J. Personal communication.

20. Baudhuin, P., H. Beaufay, Y. Rahman-Li, O. Z. Sellinger, R. Wattiaux, P. Jacques, and C. de Duve. Tissue fractionation studies. 17. Intracellular distribution of monoamine oxidase, aspartate aminotransferase, alanine aminotransferase, $\mathrm{D}$-amino acid oxidase and catalase in rat-liver tissue. Biochem. J. 1964, 92, 179.

21. Wróblewski, F., and J. S. LaDue. Lactic dehydrogenase activity in blood. Proc. Soc. exp. Biol. (N. Y.) $1955,90,210$.

22. Marcus, A. J., H. L. Ullman, L. B. Safier, and H. S. Ballard. Platelet phosphatides. Their fatty acid and aldehyde composition and activity in different clotting systems. J. clin. Invest. 1962, 41, 2198.

23. Rapaport, S. I., S. Schiffman, M. J. Patch, and A. G. Ware. A simple, specific one-stage assay for plasma thromboplastin antecedent activity. J. Lab. clin. Med. 1961, 57, 771.

24. Nye, S. W., J. B. Graham, and K. M. Brinkhous. The partial thromboplastin time as a screening test for the detection of latent bleeders. Amer. J. med. Sci. 1962, 243, 279.

25. Spaet, T. H., and J. Cintron. Studies on platelet factor-3 availability. Brit. J. Haemat. 1965, 11, 269.

26. Folch, J., M. Lees, and G. H. Sloane Stanley. A simple method for the isolation and purification of total lipides from animal tissues. J. biol. Chem. 1957, 226, 497.

27. Marcus, A. J., and D. Zucker-Franklin. Human platelet lipids and their relationship to blood coagulation. J. Amer. Oil Chemists' Soc. 1965, 42, 500.

28. Neil, M. W., and M. W. Horner. Studies on acid hydrolases in adult and foetal tissues. Acid p-nitrophenyl phosphate phosphohydrolases of adult guinea-pig liver. Biochem. J. 1964, 92, 217.

29. De Duve, C., B. C. Pressman, R. Gianetto, R. Wattiaux, and F. Appelmans. Tissue fractionation studies. 6. Intracellular distribution patterns of enzymes in rat-liver tissue. Biochem. J. 1955, 60, 604.

30. De Duve, C. The lysosome concept in Lysosomes, A. V. S. de Reuck and M. P. Cameron, Eds. Boston, Little, Brown, 1963, p. 1.

31. Appelmans, F., and C. de Duve. Tissue fractionation studies. 3. Further observations on the binding of acid phosphatase by rat-liver particles. Biochem. J. 1955, 59, 426.

32. Appelmans, F., R. Wattiaux, and C. de Duve. Tissue fractionation studies. 5 . The association of acid phosphatase with a special class of cytoplasmic granules in rat liver. Biochem. J. 1955, 59, 438.

33. Wattiaux, R., and C. de Duve. Tissue fractionation studies. 7. Release of bound hydrolases by means of Triton X-100. Biochem. J. 1956, 63, 606.

34. De Duve, C., and J. Berthet. The use of differential centrifugation in the study of tissue enzymes in International Review of Cytology, G. H. Bourne and J. F. Danielli, Eds. New York, Academic Press, 1954, vol. 3, p. 225.

35. Allfrey, V. The isolation of subcellular components in The Cell: Biochemistry, Physiology, Morphology, J. Brachet and A. E. Mirsky, Eds. New York, Academic Press, 1959, vol. 1, p. 193.

36. Tappel, A. L., P. L. Sawant, and S. Shibko. Lysosomes: distribution in animals, hydrolytic capacity and other properties in Lysosomes, A. V. S. de Reuck and M. P. Cameron, Eds. Boston, Little, Brown, 1963, p. 78.

37. Zucker, M. B., and J. Borrelli. Platelets as a source of serum acid nitrophenylphosphatase. J. clin. Invest. $1959,38,148$.

38. Parmeggiani, A. Elektronenoptische Beobachtungen an menschlichen Blutplättchen während der viskösen Metamorphose. Thrombos. Diathes. haemorrh. (Stuttg.) 1961, 6, 517.

39. Rodman, N. R., Jr., R. G. Mason, and K. M. Brinkhous. Some pathogenetic mechanisms of white thrombus formation: agglutination and self-destruction of the platelet. Fed. Proc. 1963, 22, 1356.

40. Firkin, B. G., B. J. O'Neill, B. Dunstan, and R. Oldfield. The effect of incubation and storage on human platelet structure as studied by electron microscopy. Blood 1965, 25, 345.

41. Giudici, G., and G. Turazza. Attività betaglucuronidasica e cateptica nelle piastrine di sangue umano. Minerva med. 1962, 53, 1081.

42. Giudici, G., and G. Turazza. Activités lysosomiques des plaquettes du sang humain. Hemostase 1964, 4, 91.

43. Firkin, B. G. The platelet. Aust. Ann. Med. 1963, 12, 261.

44. Berthet, J., L. Berthet, F. Appelmans, and C. de Duve. Tissue fractionation studies. 2. The nature of the linkage between acid phosphatase and mitochondria in rat-liver tissue. Biochem. J. 1951, 50, 182. 
45. Gianetto, R., and C. de Duve. Tissue fractionation studies. 4. Comparative study of the binding of acid phosphatase, $\beta$-glucuronidase and cathepsin by rat-liver particles. Biochem. J. 1955, 59, 433.

46. Miller, F., and G. E. Palade. Lytic activities in renal protein absorption droplets. An electron microscopical cytochemical study. J. Cell Biol. 1964, 23, 519.

47. Novikoff, A. B. Lysosomes in the physiology and pathology of cells: contributions of staining methods in Lysosomes, A. V. S. de Reuck and M. P. Cameron, Eds. Boston, Little, Brown, 1963, p. 36.

48. Jones, O. P. Origin of megakaryocyte granules from Golgi vesicles. Anat. Rec. 1960, 138, 105.

49. Beaufay, H., P. Jacques, P. Baudhuin, O. Z. Sellinger, J. Berthet, and C. de Duve. Tissue fractionation studies. 18. Resolution of mitochondrial fractions from rat liver into three distinct populations of cytoplasmic particles by means of density equilibration in various gradients. Biochem. J. 1964, 92, 184.

50. De Duve, C. The separation and characterization of subcellular particles. Harvey Lect. 1965, series 59, 49.
51. Bezkorovainy, A., and M. E. Rafelson, Jr. Characterization of some proteins from normal human platelets. J. Lab. clin. Med. 1964, 64, 212.

52. Horowitz, H. I., and A. J. Marcus. The development of platelet factor 3 activity by latex particles -an interaction with plasma. Blood 1964, 23, 178.

53. Horowitz, H. I. Non-sedimentable platelet factor 3 during coagulation and after immune platelet injury. Thrombos. Diathes. haemorrh. (Stuttg.) 1965 (suppl. 17), 243.

54. Shinowara, G. Y. Thromboplastic cell component, the lipoprotein of erythrocytes and platelets. J. biol. Chem. 1957, 225, 63.

55. Wallach, D. F. H., and V. B. Kamat. Plasma and cytoplasmic membrane fragments from Ehrlich ascites carcinoma. Proc. nat. Acad. Sci. (Wash.) 1964, 52, 721.

56. Nachman, R. L., A. J. Marcus, and D. Zucker-Franklin. Subcellular localization of platelet fibrinogen (abstract). Blood 1964, 24, 853.

57. Wurzel, M., A. J. Marcus, and B. W. Zweifach. Subcellular distribution of serotonin in rabbit platelets. Proc. Soc. exp. Biol. (N. Y.) 1965, 118, 468. 